\title{
OFFLINE FILING AND TRANSFER OF ELECTRONIC RECORDS AT ABC AGENCY
}

\author{
Lufi Herawan* \\ The National Archives of the Republic of Indonesia, Jakarta, Indonesia \\ *Correspondence: lufi.herawan@gmail.com
}

\begin{abstract}
The use of electronic records increases in the industrial revolution 4.0 and the implementation of WFH (Work from Home). Records management needs to be carried out on all media and types of records. Electronic records management needs to be carried out on filing and transferring records to maintain the authenticity, integrity, security, and safety of records. ABC agency already uses the Records Information System (SRIKANDI), but not all types of records can be managed using that information system. The information system cannot manage electronic records of types of photos, videos, and sound recordings. The records must be managed at $\mathrm{ABC}$ agency, so it is necessary to determine the filing and transferring the records offline. This research is qualitative research using data collection techniques: observations, interviews, and documents search. Interviews were conducted with three experts in records management, both manual and electronic. The analysis is carried out based on the stages contained in the five regulatory documents. The analysis results show that the filing stages consist of preparation, inspection, index determination, file code determination, registration/input of records information, inserting records into folders, cross-pointing (if any), labelling, and compiling a list of current records. Moreover, the transfer stage consists of preparation, selection of records, arranging semi-current records, creating a list of semi-current records to be moved, and creating a report of records transfer.
\end{abstract}

Keywords: Records management; Electronic records; Filing; Transfer

\section{INTRODUCTION}

The use of electronic records has increased in the implementation of this 4.0 industrial revolution. The implementation of Work from Home (WFH), which all organizations almost do due to the Covid-19 pandemic, has also forced employees to use electronic records to carry out daily organizational functions. According to (Mungkasa 2020, 148), working from home relies heavily on online data exchange between office employees and fellow employees, so the needed data is huge and requires systematic management. The increase in the number of electronic records needs to be balanced with reliable electronic records management to ensure the availability of records and ensure the managed records' authenticity. Electronic records management cannot be separated from information and communication technology, especially during this pandemic. Komalasari $(2020,48)$ supported this statement, where technology plays an important role in keeping community activities functioning during the Large-Scale Social Restrictions (PSBB). Records management must be carried out to keep records authentic, intact, and reliable, both for textual electronic records and other types of electronic records such as photos, videos, and sound recordings.

Electronic records management can be done using an archival/ records management information system. A free records information system that functions for electronic records management for state institutions, State-Owned Enterprises/ Regional-Owned Enterprises, both central and regional, is SRIKANDI (Integrated Electronic Records Management Information System) (Kementerian PAN \& RB 2020, 2). SRIKANDI is a general application (Electronic-Based Government System) that is the same, standardized, and used for sharing by central agencies and/or local governments (Republik Indonesia 2018, 4). SRIKANDI is also developed from the previous application, namely SIKD (Electronic Records Management Information System). Considering that the SRIKANDI application has not been able to manage electronic records in the 
form of photos, videos, and sound recordings, the ABC Agency feels the need to find ways/ procedures to be still able to manage these types of electronic records. Based on this background, the research questions in this paper can be formulated: how to file and transfer electronic records in the form of photos, videos, and sound recordings without using a records management information system (offline)?

$\mathrm{ABC}$ agency is an archival institution in the form of a non-ministerial government agency that carries out state duties in the field of archives and records (Republik Indonesia 2009, 4). Because the $\mathrm{ABC}$ agency is the executor of state duties in archives and records, what is done by the $\mathrm{ABC}$ agency will be a reference for other agencies in Indonesia on records management. The referring agencies can be state institutions at the central level or regional governments at the provincial or district or city levels, companies, political organizations, community organizations, or individuals. In addition, almost all referring agencies use the exact Records Information System as $\mathrm{ABC}$ agency (SRIKANDI) as an electronic-based government system (SPBE), where the information system has not been able to manage other types of records in the form of photos, videos, and sound recordings, so this research is essential to do.

The purpose of this study is to manage electronic records at the ABC Agency, especially filing and transferring records so that other types of electronic records can be correctly and adequately managed so that authentic, intact, and reliable records will be created. So far, many studies have discussed the management of electronic records using information systems, but not many have discussed the management of electronic records without using information systems. Many studies discuss records management online, but not much has discussed records management offline. Offline records management is used because many organisations cannot create or purchase records management information systems but still have to manage records, especially small organizations. Information systems are also sometimes limited to certain types of records. Although this is a bit old-fashioned, it can still be helpful and can be used for organizations. Electronic records management also needs to be adapted to the culture and conditions of the Indonesians. In addition, there are still many security issues when managing records online. This research will contribute to the management of electronic records in general. In particular, it will contribute to managing other types of electronic records without an information system for offline filing and transfer of records. Stages of the results of this study can be used by other agencies and organizations that have the same problem. In addition, this research can add knowledge and theory and improve existing research.

\section{LITERATURE REVIEW}

\subsection{Electronic Records}

Electronic records are records that contain information that is created, distributed, utilized, and assessed using a computer as a tool (Arsip Nasional Republik Indonesia 2009, 10). Meanwhile, according to Smallwood, electronic records are records that are created and stored electronically (Smallwood 2013, 255). Electronic records are contained in electronic storage media, generated, communicated, stored, and/or accessed using electronic equipment (Rustam 2014, 18). Electronic records are also records recorded in a special media and have special characteristics (Arsip Nasional Republik Indonesia 2009, 11). Based on this, the records in the form of photos, videos, and sound recordings produced through media transfer and born-digital in this study can be categorized as electronic records. In order to maintain the security of electronic records, security can be provided, including watermarking, electronic certificates, and other methods (Arsip Nasional Republik Indonesia 2018, 15). 


\subsection{Electronic Records Management}

Electronic records management has a life cycle that is relatively the same as the life cycle of conventional records (Arsip Nasional Republik Indonesia 2009, 11). The electronic records life cycle also has stages starting from the creation, the maintenance and use, and the disposal stage (Arsip Nasional Republik Indonesia 2009, 11) and (Republik Indonesia 2012, 20). This life cycle is a systematic control over the creation, distribution, maintenance, storage, use up to the time of its disposition (Arsip Nasional Republik Indonesia 2009, 11). Records management is carried out to ensure the availability of records in the implementation of activities as material for performance accountability and valid evidence (Arsip Nasional Republik Indonesia 2009, 27). Electronic records, both created and received in the form of current, semi-current, and vital records, consist of various types of records such as textual, photos (still visual image), video (moving image), and sound recording. According to the Head of the National Archives of the Republic of Indonesia (hereafter ANRI) Regulation Number 9 of 2018 concerning Records Maintenance (Arsip Nasional Republik Indonesia 2018, 6), some of the work that can be done in records maintenance activities is filing. In addition, according to the Regulation of the Head of ANRI Number 37 of 2016 concerning Guidelines for Records Disposal (Arsip Nasional Republik Indonesia 2016, 3-4), records disposal activities consist of transfer, destroying, and submitting archives to the Archives Institution.

\subsection{Records Filing}

Records filing is the placement of manuscripts into a set that is arranged systematically and logically according to the context of their activities; therefore, they become one with the file because they have information relations, similarities in types, or similarities in problems from a work unit (Republik Indonesia 2012, 36; Arsip Nasional Republik Indonesia 2018, 3-4). Filing is part of the records use and maintenance stage that is needed to ensure the creation of records (Arsip Nasional Republik Indonesia 2018, 5), ensure the availability of authentic and trusted records, and improve the quality of public services in the management and utilization of records (Arsip Nasional Republik Indonesia 2015, 3). These activities are essential and need to be discussed in this study because they are part of records maintenance in records management. If the records are properly maintained as a file, they will be kept safe, and their authenticity can be ensured. Besides that, it will be easily served to authorized users.

\subsection{Records Transfer}

Records disposal is an activity to reduce the number of records by transferring semicurrent records from the work unit to the archiving unit, destroying records that have no use-value, and submitting archives to archival institutions (Republik Indonesia 2012, 36) and (Arsip Nasional Republik Indonesia 2016, 2). Meanwhile, the transfer of records is a means to reduce the number of current records, which have finished their current storage period and have a shelf life as semicurrent records (Arsip Nasional Republik Indonesia 2017, 13). The next activity that needs to be discussed is the transfer which is a continuation of maintenance activities and is part of the records disposal stage. When the retention time runs out, records need to be moved to reduce records volume at the work unit. Therefore, it needs to be discussed.

Records storage is an important thing that must be done concerning filing and transferring the above records. Electronic records storage can be done online (connected), offline (disconnected), and nearline (semi-connected) (Rifauddin 2016, 174). Online storages function to store electronic records are connected to the internet network. Hence, they can be accessed anytime and from anywhere when needed. There are at least some online data storage that can be accessed for free, namely Google Grive, SkyDriver, Dropbox, Box, MadiaFire, and the records 
management information system itself. Offline storage functions to store electronic records without being connected (disconnected) with the internet network, so that it still requires human effort to access the physical records directly. Offline storage can be done by utilizing magnetic or optical media storage media such as hard disks, digital audiotapes, videotapes, compact discs (CD), video compact discs (VCD), digital versatile discs (DVD), and so on. Nearline storage functions to store semi-current electronic records resulting from records transfers that are still used as administration, but the frequency of their use has decreased. This nearline storage requires facilities and infrastructure that allow access to records from the previous offline condition with minimal human intervention. This study will focus on offline storage for both records filing activities and records disposal according to the formulation of the problem above. Offline records storage was chosen to secure records from access by unauthorized persons. In this case, accessing the records requires obtaining permission from the records management officer so that the records will be more secure.

\subsection{Records Management Information System}

There are several records management information systems that can be used to manage electronic records, such as Enterprise Content Management (ECM), Electronic Document Management System (EDMS), Electronic Records Management (ERM/ERMS) (Smallwood 2013, 35-40). There is also an information system that has a special function for records filing, namely SIARIP (Records Filing Information System) (Herawan and Muslimah 2020, 138). Various information systems and applications for managing electronic records have been widely available, both free and paid and built by themselves. A free records management information system that functions to manage records is SRIKANDI (Integrated Records Management Information System). SRIKANDI is also developed from the previous application, namely SIKD (Records Management Information System) (Herawan 2021).

\subsection{Research Framework}

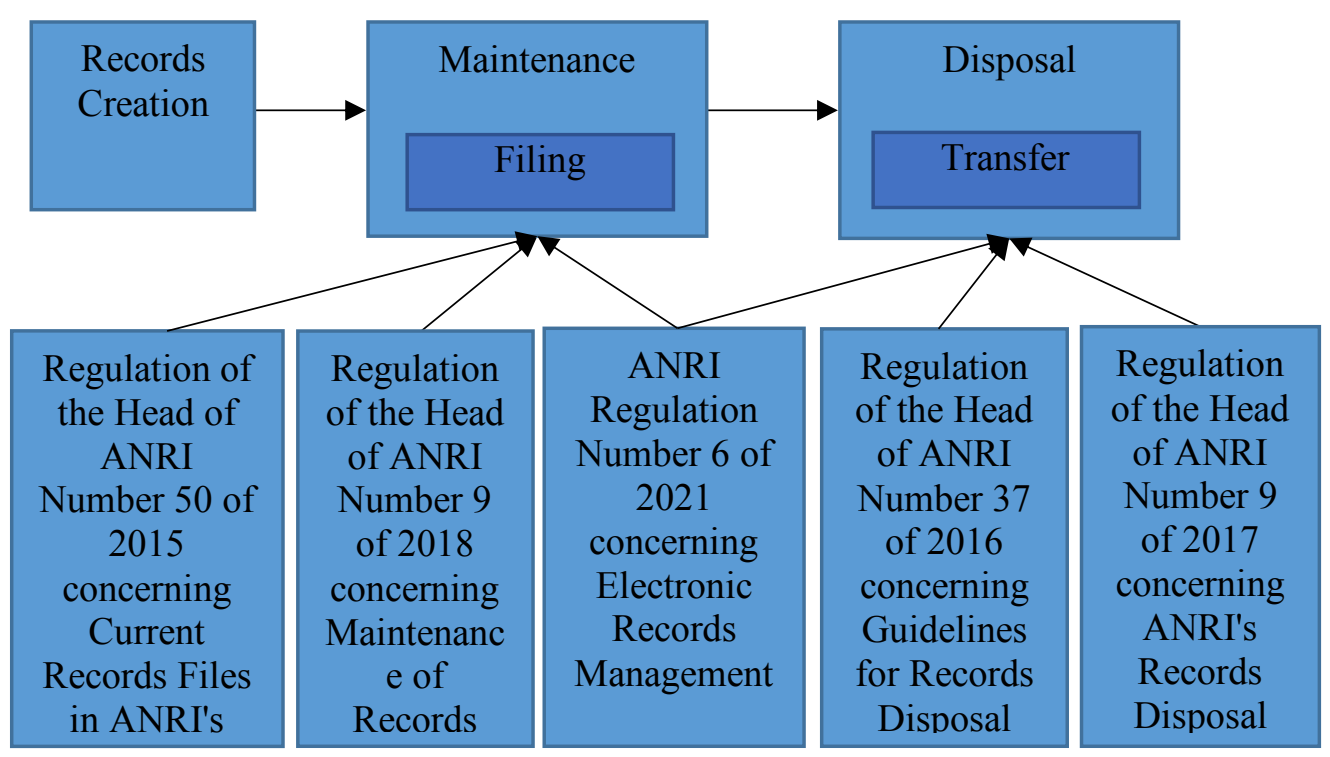

Figure 1. Research Framework

The framework is a chart that can explain how this research will be carried out. This framework contains the theory used to perform records maintenance and disposal. Maintenance is in the form of electronic records filing and disposal in the form of electronic records transfer. 
Electronic records that will be filed and transferred are electronic records of types of photos, videos, and sound recordings. The research will be carried out following the framework set out in Figure 1 above.

The above framework will be used as a basis for filing and transferring electronic records. This framework can be described as follows:

1. Records creation consists of creating and receiving. At the $\mathrm{ABC}$ agency, the electronic records created are the born-digital electronic records. It means that the electronic records are directly made from the device used. For example, digital cameras are tools for creating electronic photo records, handy cams and laptops with zoom applications are tools for creating electronic photo and video records, and voice recorders are tools for creating voice recording records. After the records are created, they will be used for the benefit of the organization. In order to maintain the authenticity, integrity, and trustworthiness of the records that have been created, it is necessary to maintain records.

2. Records maintenance, according to the Regulation of the Head of ANRI Number 9 of 2018 concerning Records Maintenance (Arsip Nasional Republik Indonesia 2018, 2), is maintaining the integrity, security, and safety of records, both physical and information, which includes filing and storage of current records, structuring and storing semi-current records, and transfer media records. Maintenance activities in this study are limited only to current records filing and storage because this is the first step that must be done before the records are used or accessed. Records file will keep the records intact, safe and secure. Filing, according to the Regulation of the Head of ANRI Number 9 of 2018 concerning Records Maintenance (Arsip Nasional Republik Indonesia 2018, 3) and the Regulation of the Head of ANRI Number 50 of 2015 concerning Filing of Current Records in ANRI's Central Files (Arsip Nasional Republik Indonesia 2015, 7), is the placement of manuscripts into a set that arranged systematically and logically according to the context of its activities. Therefore, it becomes a single file because it has information relations, similar types or similar problems from work units. The stages of filing records consist of inspection, index determination, code determination, cross-examination, labelling, and compilation of current records lists (Arsip Nasional Republik Indonesia 2018, 17). In addition, it is also necessary to consider ANRI Regulation Number 6 of 2021 regarding records management, especially related to the use, storage and maintenance of electronic records, which are part of electronic records management (Arsip Nasional Republik Indonesia 2021, 9).

3. Records disposal, according to the Regulation of the Head of ANRI Number 37 of 2016 concerning Records Disposal Guidelines (Arsip Nasional Republik Indonesia 2016, 2), is an activity to reduce the number of records by transferring semi-current records from the work unit to the archiving unit (Arsip Nasional Republik Indonesia 2017, 4), destroying records that have no use-value, and submission of archives to archival institutions. Disposal activities in this study are limited to records transfer activities because this is a continuation of records filing activities. Transfers are made to records that have been filed if the records have run out of active retention. Transferring semi-current records consists of selecting semi-current records, arranging semi-current records, and making a list of semi-current records (Arsip Nasional Republik Indonesia 2016, 2 Appendix) and (Arsip Nasional Republik Indonesia 2017, 14). In addition, it is also necessary to consider ANRI Regulation Number 6 of 2021 for Electronic Records Management related to the disposal of electronic records (Arsip Nasional Republik Indonesia 2021, 15). 


\section{METHOD}

This research is qualitative research using data collection techniques in the form of observations, interviews, and documents search. According to Sugiyono (2013, 347), qualitative research methods can be interpreted as research methods based on postpositivism/interpretive philosophy. It is used to research on natural subject conditions, where the researcher is the key instrument. Data collection techniques are carried out by triangulation (combined), analysis the data are inductive/qualitative, and the results of qualitative research emphasize meaning rather than generalizations. This study will investigate the management of electronic records in natural conditions following the conditions that exist in the records creator, using combined data collection techniques and qualitative data analysis. The data collection in this study was sourced from secondary data obtained through other people or existing documents. The technique or method of collecting data in this research is conducted by observations, interviews, and documents search. The research methodology can be outlined in Figure 2. The research methodology outlined in the research stages is used as a reference for implementation in this study.

Figure 2 shows the research stages that will be passed, starting from the initial data collection, problem formulation, carrying out a literature review, followed by data collection and discussion of results and conclusions. The stages can be explained as follows:

1. Initial data collection. It is carried out through observation, review of regulations and documents, and initial interviews regarding the management of other types of electronic records. According to observations, the management of other record types cannot be carried out through the SRIKANDI application. According to interviews with records management officers in the Public Relations Division, one of the work units that manage other types of records, data obtained for 2020 consist of managing photos of 190 activities and managing video of 74 activities. With the creation of records, the word unit is obliged to manage the records to ensure the realization of reliable and valuable records (Republik Indonesia 2009, 8). In addition, records maintenance needs to be done to maintain the authenticity, integrity, security, and safety of records (Republik Indonesia 2012, 22).

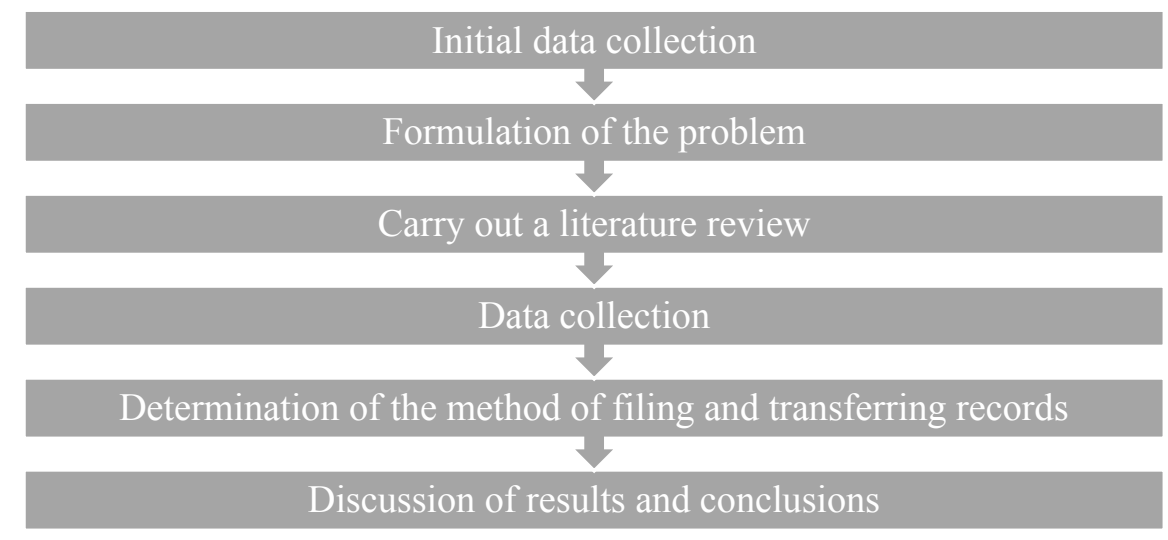

Figure 2. Research Stages

2. Formulation of the problem. Problems can be formulated based on the results obtained from the initial data collection. The problem formulation process is related to records management, consisting of several activities, namely creation, use and maintenance, and disposal. After analyzing the problem formulation, it will focus on filing and transferring records because these two activities are the most important activities to ensure the authenticity, integrity, security, and safety of records. Files that are part of records maintenance will keep the records intact in one file and maintain its physical and information security. While the transfer of 
records is part of depreciation and is a continuation of the records filing process, the transfer process must be carried out first to be recognised as semi-current records. The transfer process is carried out through an official report and a list of semi-current records transferred as a form of transfer of authority from the work unit to the archiving unit. The transfer considers the form and media of records, including electronic media (Republik Indonesia 2012, 30).

3. Carry out a literature review. The literature review is carried out by searching for and studying the regulations and theories related to the research question.

4. Data collection. Advanced data collection to complement the existing initial data. It is carried out through observation, review of regulations and documents, and interviews regarding the management of other types of electronic records. Observations were made on managing electronic records in the work unit, including the General Affair and the Public Relations Division. The General Affair is related to work units that implement the SRIKANDI application, while the Public Relations Division is related to work units that have other types of records (photos, videos, and sound recordings). The regulations under review can be seen in Table 1 below.

Tabel 1. List of Records Regulation

\begin{tabular}{|c|l|c|}
\hline No & \multicolumn{1}{|c|}{ Records Regulation } & Description \\
\hline 1 & $\begin{array}{l}\text { ANRI Regulation Number 6 of 2021 concerning Electronic Records } \\
\text { Management }\end{array}$ & $\begin{array}{c}\text { Records Filing \& } \\
\text { Transfer }\end{array}$ \\
\hline 2 & $\begin{array}{l}\text { Regulation of the Head of ANRI Number 9 of 2018 concerning } \\
\text { Maintenance of Records }\end{array}$ & Records Filing \\
\hline 3 & $\begin{array}{l}\text { Regulation of the Head of ANRI Number 50 of 2015 concerning Current } \\
\text { Records Files in ANRI's Central Files. }\end{array}$ & Records Filing \\
\hline 4 & $\begin{array}{l}\text { Regulation of the Head of ANRI Number 9 of 2017 concerning ANRI's } \\
\text { Records Disposal }\end{array}$ & Records Transfer \\
\hline 5 & $\begin{array}{l}\text { Regulation of the Head of ANRI Number 37 of 2016 concerning } \\
\text { Guidelines for Records Disposal }\end{array}$ & Records Transfer \\
\hline
\end{tabular}

Interviews were conducted with three experts who understand and master records management, especially the filing and transfer of electronic records. The interview was conducted through the Whatsapp application on Wednesday, July 28, 2021, using open-ended questions about the stages of filing and transferring records. Archivist experts interviewed can be seen in Table 2 below.

Tabel 2. List of Respondents

\begin{tabular}{|c|l|c|c|c|}
\hline No & \multicolumn{1}{|c|}{ Name } & Position & Work Unit & Description \\
\hline 1 & Drs.Bambang Parjono & Senior & Deputy for Archival \\
Widodo, M.SI & Archivist & Archelopment & \\
\hline 2 & Dra.Dwi Mudalsih, & Senior & Directorate of Central & Ministry/Agency Archives \\
& M.Hum & Archivist & Archival Development & Development Unit \\
\hline 3 & Sutiana, S.Kom, & Senior & Center of Data and & Technology, Information \& \\
& MAP & Archivist & Information & Communication Unit \\
\hline
\end{tabular}

5. Determination of the method of filing and transferring other types of records. Determination of records filing methods and records transfer to be used in electronic records management according to research questions. The determination is based on the analysis obtained from data collection in the previous stage.

6. Discussion of results and conclusions. The discussion is carried out from the results of determining the method, and conclusions are made from this study's results. 


\section{RESULTS AND DISCUSSION}

\subsection{Records Filing}

The stages of records filing have been regulated by the Regulation of the Head of ANRI Number 9 of 2018 concerning Records Maintenance, which consists of inspection, index determination, code determination, cross-examination, labelling, and compilation of current records lists (Arsip Nasional Republik Indonesia 2018, 17). In addition, for the stage of filing within the agency, an example of an ANRI agency that already has an internal agency regulation in the form of the Head of ANRI Regulation Number 50 of 2015 concerning Current Records Filing in the ANRI 's Central File. The filing stages in the regulation consist of examination, determination of index, determination of classification according to the classification scheme, registration of records, inserting records into folders, cross-pointing if necessary, labelling, and compiling a list of current records (Arsip Nasional Republik Indonesia 2015, 21). The stages in the two regulations are not mentioned explicitly for one type of record so that it is possible to use it to file electronic records. It is necessary to analyze whether these stages need to be adjusted for electronic records. That is when the filing is done on electronic records without using an information system (offline). In addition to these two regulations, some regulations specifically regulate electronic records (ANRI Regulation Number 6 of 2021 concerning Electronic Records Management), but they do not discuss in detail the stages of filing. The results of the analysis process of the records filing stages can be seen in Appendix 1.

From the results, the steps that can be carried out on filing electronic records for types of photos, videos, and voice recordings without an information system (offline) are as follows: inspection, determination of index, determination of filing code (classification), registration/input of records information, inserting records into folders, cross-pointing (if any), labelling, compiling a list of current records. For more details, the steps can be explained as follows:

\section{Preparation.}

Each work unit can carry out preparatory activities at the records creator. The work unit will carry out activities, produce, and maintain records for use, especially filing. The preparation must include a computer device with storage media in it. Offline filing can use the hard disk as a records storage medium. In order to provide security, the computer should be given a password to $\log$ in and determine which users have the right to use the computer device. Users can be archivists or records managers who have a job to manage records in the processing unit environment.

Other removable storage media, such as external hard disks can be used if the hard disk capacity on the computer is not sufficient to store other types of records, considering that photo, video, and sound recording records have a larger file capacity than textual records. The use of other media also requires security. Computers and the use of removable media require physical security and information security. Physical security can be done by storing it in a safe place and locking it. Security can be provided in the form of a password on the computer and the external device for information security. The use of removable storage media needs to pay attention to the age of the storage media (lifetime). So when the age of the media is about to run out, the archiver must immediately replace the storage media used. It is necessary to avoid the loss of records due to damage to storage media due to their age.

Another preparation that needs to be done is to install all the necessary applications, such as a records reader application. Make sure all applications are installed and able to read all the records that we save. An example of a records reader application with a PDF extension is PDF Reader. The application can be installed on the computer in use or where the hard disk is used to store the records. 


\section{Inspection.}

Checks are carried out to ensure that each electronic file to be filed is authentic, intact, and complete in every activity process. Electronic records can be the result of media transfer or born-digital electronic records. For records resulting from the media transfer, it should be equipped with an official report and a list of records carried out by media transfer. In addition to the electronic records being authentic, intact, and complete, the archives must ensure that they can be opened and accessed.

\section{Determination of Index.}

The index (file title) is given by determining the catchword (keyword) of the records to represent the information content of the file/file content. The index can be the person's name, institution/organization, place/region, problem, and period. Writing the index is conducted after writing the records classification code on the folder. The stages of determining the index can be written as follows: Before writing the index and classification code, write down the file's serial number. File numbering is given according to the numbering on the list of the current records. The serial numbering of these files is conducted for easy searching, and it will keep the list sorted in folders. The writing of the index on the folder can be seen in Figure 3 below.

KA.03 Penyusutan

KA.03.00 Pemindahan Arsip

1 KA.03.00 Pemindahan Arsip Direktorat Kearsipan Pusat 2019

2 KA.03.00 Pemindahan Arsip Direktorat Pengolahan 2019

3 KA.03.00 Pemindahan Arsip Biro Organisasi, Kepegawaian dan Hukum

KA.03.01 Pemusnahan Arsip

Figure 3. Writing the Index to the folder

\section{Determination of Filing Code (Classification).}

The determination of the filing code is carried out according to the functions, activities, and transactions carried out by the work unit according to the classification code. Determination of the file code is like installing a guide on a filing cabinet. The determination of the file code for the folder on the computer can be seen in Figure 4 below.

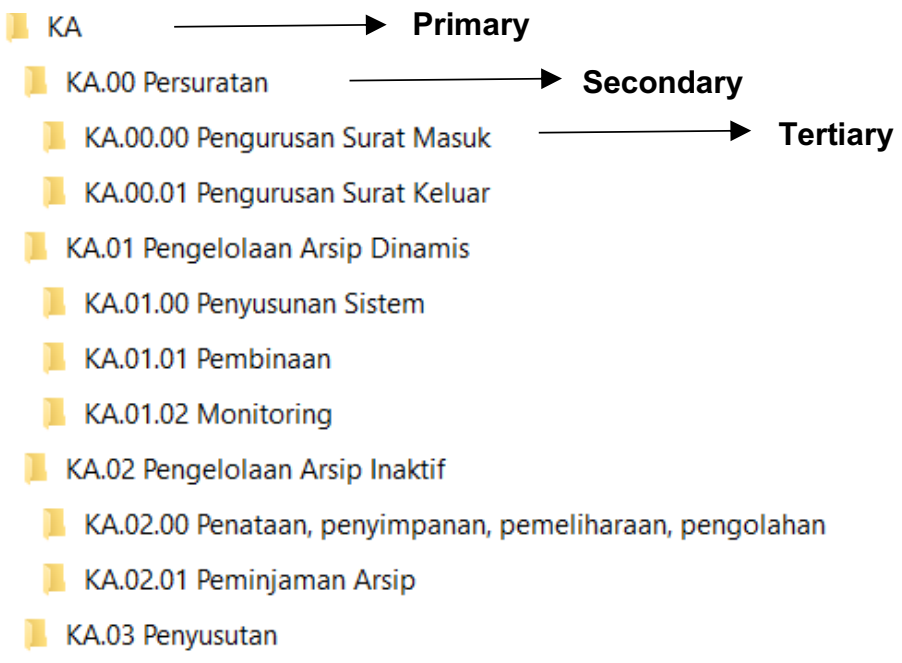

Figure 4. Determination of filing code (classification) 


\section{Registration/ Input of Records Information.}

Register/ input record information is based on the contents of the records. Registration/ input of records information is customized to the contents of the files (records items) in the folder. Records are arranged chronologically by giving the number of records items. The oldest file is numbered one and so on until the youngest file. The records item number must match the records item number in the file's table of contents. Writing on the records file can be seen in Figure 5 below.

\section{Pembukaan Rapat Koordinasi Kearsipan Oleh Kepala ANRI \\ 2 Sambutan Menteri PAN dan RB acara Rapat Koordinasi Kearsipan \\ 3 Pengumuman Hasil Pengawasan Kearsipan 2020 \\ 4 Penutupan Kegiatan Rapat Koordinasi}

Figure 5. Registration/ Input records information

\section{Inserting Records Into Folders.}

Entering records that have been registered/inputting records information into a folder that has been indexed. The entered records are arranged sequentially according to chronological time. Then, record information is registered according to point number 5 .

7. Cross-pointing (if any).

Cross-pointing is only used if the file contains information on more than one function execution. Cross-pointing is also used for records with information related to other files with different types of records and media or in different locations. In addition, cross-pointing can also be used if an object has changed its name, be it a person, employee, or institution.

Cross-pointing can be done by writing a description about the folder's location using the folder's serial number, classification code, index, and the used records media. Location information can also be written in the description column contained in the list of current records. Cross-linking can also be completed with a cross-examination file form that can be created and put into two cross-linked folders. Previously the form was made into an electronic form with a pdf extension.

\section{Labelling.}

Labelling for electronic records is carried out in the form of writing information on a folder in a computer according to the above provisions, be it file codes, classification and index codes, and file naming.

\section{Compiling a List of Current Records.}

Electronic current records filing must be accompanied by a list of current records in the form of a list of files and file contents. The format of the list of the current records can be customized according to the provisions of the existing current records list. Making a list of current records should also pay attention to the types of records that exist, such as photos, videos, and sound recording records.

\subsection{Records Transfer}

Records transfer reduces the number of records by moving current records from the work unit to the archiving unit (Arsip Nasional Republik Indonesia 2016, 2) and (Arsip Nasional Republik Indonesia 2017, 4). Records transfer activities are regulated in the Head of ANRI Regulation Number 37 of 2016 concerning Records Disposal Guidelines. In addition, records transfer activities are also regulated in the Regulation of the Head of ANRI Number 9 of 2017 concerning Records Disposal in the ANRI Environment. In addition to paying attention to records 
media, the transfer of semi-current records is carried out through activities: selecting semi-current records, arranging semi-current records, and making a list of semi-current records to be moved (Arsip Nasional Republik Indonesia 2016, 2 attachment) and (Arsip Nasional Republik Indonesia 2017, 14). A report and a list of files to be moved accompanies the transfer of semi-current records. In addition to these two regulations, some regulations specifically regulate electronic records (ANRI Regulation Number 6 of 2021 concerning Electronic Records Management). However, these regulations only regulate the disposal stages of electronic records in the form of submission and destruction of records. The transfer activities in the two regulations are not mentioned explicitly for one type of record, so that it is possible to use it to file electronic records. It is necessary to analyze whether these activities need to be adapted for electronic records transferred without using an information system (offline). The analysis results of the records transfer process stages can be seen in Appendix 2.

The transfer of electronic records of the photos, videos, and sound recordings without an information system (offline) obtained the following results: semi-current records selection, arranging semi-current records, and creating a list of semi-current records to be moved, and creating a report of records transfer. For more details, the steps can be explained as follows:

\section{Preparation}

Each work unit can carry out preparatory activities at the records creator. The preparation must include providing storage media for the implementation of records transfer. Media that can be used includes external hard drives, CDs, and others. The provision of records transfer media can be customized based on the type of records to be moved. The transfer of electronic semi-current records also pays attention to the form or type of records media.

\section{Semi-Current Records Selection}

The selection of semi-current records to be transferred is conducted using the agency's JRA (Records Retention Schedule). For the time being, there is no distinction between JRA for electronic and non-electronic records. The selection process can be done either manually or automatically. The implementation of manual selection can be seen from the time records created with the retention of existing records. If it has run out and has passed, it can be moved. Automatic selection of records can be carried out by the system or application, which gives us information when certain records have been exhausted or have missed their retention and can be moved. It needs to be done because the retention of records varies; even within one year of creating the identical records, there are also differences in retention. Therefore, there may be records that have not yet exhausted their retention in one year, and records that have exhausted their retention need to be moved.

\section{Arranging Semi-Current Records}

After finding records to be moved, the next step is to organize them against all exhausted or missed retention records. The steps for structuring semi-current records consist of:

a. Organize the folder (file) to be moved. Provide a serial number in the folder where the electronic records are stored. The folder number must match the list of records that will be created later.

b. Save and insert a semi-current records folder containing electronic media into the media used for the transfer of records according to the preparation stage above. For example, external hard disk, $\mathrm{CD}$, or other media.

c. Label the media used in point $b$, using paper affixed to the media. For example, a label can be affixed to the CD's cover or the surface, which is not read by the computer. For an external hard drive, a label can be given to the outer surface of the external hard drive. 


\section{Creating a List of Semi-Current Records to be Moved}

The next activity is to make a list of semi-current records that will be transferred in the form of a list of files and file contents according to the legislation's mandate. The format of the list of semi-current records to be moved can be customized based on the provisions of active files' existing list. Making a list of semi-current records to be moved should also consider the types of existing records, such as photos, videos, sound recording records, and storage media. The list of semi-current records to be moved must match the physical records to be moved.

\section{Creating Report of Records Transfer}

The last stage of the records transfers activity is making an official report on the transfer of semi-current records that must be signed by both parties, the head of the work unit and the head of the archive unit. It is essential because it is a transfer of authority and responsibility from each unit, where the work unit provides semi-current records with their authorities and responsibilities. The archives unit receives semi-current records and their authority and responsibility for managing semi-current records so that they remain authentic, intact, and reliable.

\subsection{Discussion}

Based on the research results, although information systems are not used in managing electronic records, it is necessary to know the factors that influence the application of information systems. It is still appropriate because the records that are managed are electronic. Based on Novita $(2014,52)$, there are several obstacles to the development of e-government, including infrastructure constraints (digital divide and weak regulation), organization (lack of coordination), and human resources (HR). It is also supported by Herawan $(2018,440)$, who states that factors that must be considered in implementing the system include the dimensions of human resources (user training, self-efficacy, perceived value of records), organizational dimensions (facilitating conditions and top management support), and the technology dimension (facilitating condition). In order to overcome HR constraints, it is necessary to disseminate information to records management staff to manage electronic records. Besides that, regular training can also be given about the importance of records and how to manage records. To overcome organizational constraints, it is necessary to coordinate work units and records units and provide suitable facilities for managing records. In addition, to overcome infrastructure or technological constraints, it is necessary to establish an electronic records management policy following existing procedures, and all leaders must be able to support the implementation of records management activities. Based on the above discussion, $\mathrm{ABC}$ agencies can manage electronic records because it does not necessarily use a records information system. Therefore, there is no need for specialized human resources and specialized infrastructure/ technology. The filing procedure can still be done only by using a computer device. Moreover, the records transfer can be recorded onto a CD or other media.

\section{CONCLUSION}

Maintenance and disposal of records, which is part of records management, is a very important activity. Records management is also carried out for electronic records, whether using a records information system or not. In $\mathrm{ABC}$ institutions, because they do not have the stage of managing, especially electronic records, without an information system, it is necessary to determine the stages of implementation, especially filing and transfer. Electronic records filing is part of maintenance, which after the analysis and consist of preparation, inspection, index determination, filing code determination, registration/input of records information, inserting 
records into folders, cross-pointing (if any), labelling, and compiling current records list. The transfer of electronic records is part of the records disposal, which, after the analysis is carried out, consist of stages: preparation, selection of semi-current records, arrangement of semi-current records, and making a list of semi-current records to be moved. Meanwhile, semi-current records arrangement activities consist of arranging folders to be moved, storing and inserting them on the media, and giving labels to the media used.

\section{BIBLIOGRAPHY}

Arsip Nasional Republik Indonesia. 2009. Modul Manajemen Arsip Elektronik. Jakarta: Arsip Nasional Republik Indonesia.

-. 2021. Peraturan Arsip Nasional Republik Indonesia Nomor 6 Tahun 2021 tentang Pengelolaan Arsip Elektronik. Jakarta: Arsip Nasional Republik Indonesia.

-. 2016. Peraturan Kepala Arsip Nasional Republik Indonesia Nomor 37 Tahun 2016 tentang Pedoman Penyusutan Arsip. Jakarta: Arsip Nasional Republik Indonesia.

-. 2015. Peraturan Kepala Arsip Nasional Republik Indonesia Nomor 50 Tahun 2015 tentang Pemberkasan Arsip Aktif di Central File di Lingkungan ANRI. Jakarta: Arsip Nasional Republik Indonesia.

- 2017. Peraturan Kepala Arsip Nasional Republik Indonesia Nomor 9 Tahun 2017 tentang Pedoman Penyusutan Arsip di Lingkungan ANRI. Jakarta: Arsip Nasional Republik Indonesia.

- 2018. Peraturan Kepala Arsip Nasional Republik Indonesia Nomor 9 Tahun 2018 tentang Pemeliharaan Arsip Dinamis. Jakarta: Arsip Nasional Republik Indonesia.

Herawan, Lufi. 2021. "Factor Affecting the Implementation of SIKD at the National Archives of the Republic of Indonesia." 2021 International Conference on Science and Technology. Yogyakarta.

Herawan, Lufi, and Alfiana Indah Muslimah. 2020. "Technical Training for Sel-Efficacy Improvement of SIARIP User at the National Archives of the Republic of Indonesia." 2020 International Conference on Information Technology System and Innovation (ICITSI). Bandung-Padang: IEEE Xplore. 137-142.

Herawan, Lufi, and Dana Indra Sensuse. 2018. "Analysis of Factors for Adoption and Use of AtoM in Indonesia." 2018 International Conference on Information Technology Systems and Innovation (ICITSI). Bandung-Padang: IEEE Xplore. 436-441.

Kementerian PAN dan RB. 2020. Keputusan Menteri Pendayagunaan Aparatur Negara dan Reformasi Birokrasi Republik Indonesia Nomor 679 Tahun 2020 tentang Aplikasi Umum Bidang Kearsipan Dinamis. Jakarta: Kementerian Pendayagunaan Aparatur Negara dan Reformasi Birokrasi.

Komalasari, Rita. 2020. "Manfaat Teknologi Informasi dan Komunikasi di Masa Pandemi Covid 19." TEMATIK-Jurnal Teknologi dan Komunikasi 7(1).

Mungkasa, Oswar. 2020. "Bekerja dari Rumah (Working From Home/ WFH): Menuju Tatanan Baru Era Pandemi COVID-19." The Indonesian Journal of Development Planning 4(2).

Novita, Dien. 2014. "Faktor-Faktor Penghambat Pengembangan E-Government: Studi Kasus Pemerintah Kota Palembang, Sumatera Selatan.” Eksplora Informatika 4(1):43-52.

Republik Indonesia. 2012. Peraturan Pemerintah Republik Indonesia Nomro 28 Tahun 2012 tentang Pelaksanaan Undang-Undang Nomor 43 Tahun 2009 tentang Kearsipan. Jakarta: Sekretaris Negara.

—. 2018. Peraturan Presiden RepubliK Indonesia Nomor 95 Tahun 95 Tahun 2018 tentang Sistem Pemerintah Berbasis Elektronik. Jakarta: Sekretaris Negara. 
-. 2009. Undang-Undang Republik Indonesia Nomor 43 Tahun 2009 tentang Kearsipan. Jakarta: Sekretariat Negara.

Rifaudin, M. 2016. "Pengelolaan Arsip Elektronik Berbasis Teknologi." Khizanah Al-Hikmah Jurnal Ilmu Perpustakaan, Informasi, dan Kearsipan 4(2):168-178.

Rustam, Muhammad. 2014. "Pengantar Pengelolaan Arsip Elektronik." In Pengelolaan Arsip Elektronik, 1-85. Jakarta: Universitas Terbuka.

Smallwood, Robert F. 2013. Managing Electronic Records: Methodes, Best Practices, and Technologies. New Jersey: John Wiley \& Sons. Inc.

Sugiyono. 2013. Metode Penelitian Manajemen. Bandung: Alfabeta. 


\section{Appendix 1}

Records Filing Stages Analysis

\begin{tabular}{|c|c|c|c|c|c|c|}
\hline No & $\begin{array}{c}\text { Regulation of the } \\
\text { Head of ANRI } \\
\text { Number } 50 \text { of } \\
2015\end{array}$ & $\begin{array}{c}\text { Regulation of } \\
\text { the Head of } \\
\text { ANRI } \\
\text { Number } 9 \text { of } \\
2018 \\
\end{array}$ & $\begin{array}{c}\text { ANRI } \\
\text { Regulation } \\
\text { Number } 6 \\
\text { of } 2021\end{array}$ & $\begin{array}{l}\text { Interview } \\
\text { Result }\end{array}$ & $\begin{array}{c}\text { Analysis for Electronic } \\
\text { Records }\end{array}$ & $\begin{array}{l}\text { Conclu } \\
\text { sion }\end{array}$ \\
\hline 1 & Inspection & Inspection & - & Inspection & $\begin{array}{l}\text { Electronic records require } \\
\text { a series of inspections to } \\
\text { ensure authenticity, } \\
\text { integrity, and } \\
\text { completeness. }\end{array}$ & Used \\
\hline 2 & $\begin{array}{l}\text { Index } \\
\text { Determination }\end{array}$ & $\begin{array}{l}\text { Index } \\
\text { Determination }\end{array}$ & - & $\begin{array}{l}\text { Index } \\
\text { Determination }\end{array}$ & $\begin{array}{l}\text { Need to define an index } \\
\text { to group records that } \\
\text { represent file } \\
\text { information. }\end{array}$ & Used \\
\hline 3 & $\begin{array}{l}\text { Determination of } \\
\text { Classification } \\
\text { according to the } \\
\text { classification } \\
\text { scheme }\end{array}$ & $\begin{array}{l}\text { Determination } \\
\text { of File Code } \\
\text { (classification } \\
\text { ) }\end{array}$ & - & $\begin{array}{l}\text { Determination } \\
\text { of File Code } \\
\text { (classification) }\end{array}$ & $\begin{array}{l}\text { It is necessary to } \\
\text { determine the file code in } \\
\text { the form of a records } \\
\text { classification code at the } \\
\text { records creator. }\end{array}$ & Used \\
\hline 4 & $\begin{array}{l}\text { Records } \\
\text { Registration }\end{array}$ & - & $\begin{array}{l}\text { Records } \\
\text { Informatio } \\
\text { n Input }\end{array}$ & - & $\begin{array}{l}\text { If you don't use an } \\
\text { information system, you } \\
\text { need to process records } \\
\text { information input, but if } \\
\text { you use an information } \\
\text { system it is not necessary } \\
\text { because the existing } \\
\text { information is already } \\
\text { registered in the } \\
\text { information system in the } \\
\text { form of metadata. }\end{array}$ & Used \\
\hline 5 & $\begin{array}{l}\text { Put the records } \\
\text { into a folder } \\
\text { (chronologically) }\end{array}$ & - & - & - & $\begin{array}{l}\text { Need to put the } \\
\text { appropriate files into } \\
\text { folders, and sorted } \\
\text { chronologically. }\end{array}$ & Used \\
\hline 6 & $\begin{array}{l}\text { Cross Point (if } \\
\text { any) }\end{array}$ & $\begin{array}{l}\text { Cross Point (if } \\
\text { any) }\end{array}$ & - & $\begin{array}{l}\text { Cross Point (if } \\
\text { any) }\end{array}$ & $\begin{array}{l}\text { Cross-pointing is } \\
\text { necessary if there are } \\
\text { records that: } \\
\text { a. Have information on } \\
\text { more than one } \\
\text { function; } \\
\text { b. Having information } \\
\text { linkages with other } \\
\text { files with different } \\
\text { media; } \\
\text { c. Change the name of a } \\
\text { person or employee or } \\
\text { institution. } \\
\end{array}$ & Used \\
\hline 7 & Labeling & Labeling & - & Labeling & $\begin{array}{l}\text { Need to be written on the } \\
\text { folder as a file identifier. }\end{array}$ & Used \\
\hline 8 & $\begin{array}{l}\text { Compilation of } \\
\text { Current Records } \\
\text { Lists }\end{array}$ & $\begin{array}{l}\text { Compilation } \\
\text { of Current } \\
\text { Records Lists }\end{array}$ & - & $\begin{array}{l}\text { Compilation of } \\
\text { Current } \\
\text { Records Lists }\end{array}$ & $\begin{array}{l}\text { It is necessary to compile } \\
\text { a current records list } \\
\text { consisting of a list of files } \\
\text { and a list of file contents. }\end{array}$ & Used \\
\hline
\end{tabular}




\section{Appendix 2}

Records Transfer Stage Analysis

\begin{tabular}{|c|c|c|c|c|c|}
\hline No & $\begin{array}{c}\text { Regulation of the } \\
\text { Head of ANRI } \\
\text { Number } 37 \text { of } \\
2016\end{array}$ & $\begin{array}{l}\text { Regulation of the } \\
\text { Head of ANRI } \\
\text { Number } 9 \text { of } \\
2017\end{array}$ & Interview Result & $\begin{array}{c}\text { Analysis for Electronic } \\
\text { Records }\end{array}$ & $\begin{array}{l}\text { Conclu } \\
\text { sion }\end{array}$ \\
\hline 1 & $\begin{array}{l}\text { Semi-Current } \\
\text { Records } \\
\text { Selection. Using a } \\
\text { JRA (Archive } \\
\text { Retention } \\
\text { Schedule) where } \\
\text { the active } \\
\text { retention has been } \\
\text { exhausted or } \\
\text { exceeded. }\end{array}$ & $\begin{array}{l}\text { Semi-Current } \\
\text { Records Selection. } \\
\text { Using a JRA } \\
\text { (Archive } \\
\text { Retention } \\
\text { Schedule) where } \\
\text { the active } \\
\text { retention has been } \\
\text { exhausted or } \\
\text { exceeded. }\end{array}$ & $\begin{array}{l}\text { Semi-Current } \\
\text { Archive } \\
\text { Selection. }\end{array}$ & $\begin{array}{l}\text { It is necessary to select the } \\
\text { records that have exhausted } \\
\text { their retention. The retention } \\
\text { used is Records Creator } \\
\text { Retention. Selection can be } \\
\text { done manually or automatically. }\end{array}$ & Used \\
\hline 2 & $\begin{array}{l}\text { Arranging Semi- } \\
\text { Current Records: } \\
\text { a. Organize } \\
\text { folders/files to } \\
\text { be moved } \\
\text { based on the } \\
\text { serial number } \\
\text { of the list of } \\
\text { semi-current } \\
\text { records to be } \\
\text { moved; } \\
\text { b. Save and insert } \\
\text { semi-current } \\
\text { records } \\
\text { folders/files } \\
\text { into the box; } \\
\text { c. Label the } \\
\text { records box. }\end{array}$ & $\begin{array}{l}\text { Arranging Semi- } \\
\text { Current Records: } \\
\text { a. Organize } \\
\text { folders/files to } \\
\text { be moved } \\
\text { based on the } \\
\text { serial number } \\
\text { of the list of } \\
\text { semi-current } \\
\text { records to be } \\
\text { moved; } \\
\text { b. Save and insert } \\
\text { semi-current } \\
\text { records } \\
\text { folders/files } \\
\text { into the box; } \\
\text { c. Label the } \\
\text { records box. }\end{array}$ & $\begin{array}{l}\text { Arranging Semi- } \\
\text { Current Records: } \\
\text { a. Organize } \\
\text { folders/files to } \\
\text { be moved } \\
\text { based on the } \\
\text { serial number } \\
\text { of the list of } \\
\text { semi-current } \\
\text { records to be } \\
\text { moved; } \\
\text { b. Save and insert } \\
\text { semi-current } \\
\text { records } \\
\text { folders/files } \\
\text { into the box; } \\
\text { c. Label the } \\
\text { records box. }\end{array}$ & $\begin{array}{l}\text { It is necessary to arrange semi- } \\
\text { current records to be moved. } \\
\text { a. Need to organize the } \\
\text { folders/files to be moved and } \\
\text { given the serial number of } \\
\text { the folder. The folder number } \\
\text { must match the list of records } \\
\text { that will be created later; } \\
\text { b. Save and insert semi-current } \\
\text { records folders/files into } \\
\text { records storage media which } \\
\text { will be submitted to the } \\
\text { records unit. For examples } \\
\text { external hard drives, CDs, \& } \\
\text { other media; } \\
\text { c. Labeling the media used as in } \\
\text { point b, using paper affixed } \\
\text { to the media. }\end{array}$ & Used \\
\hline 3 & $\begin{array}{l}\text { Creating a List of } \\
\text { semi-current } \\
\text { records to be } \\
\text { moved. }\end{array}$ & $\begin{array}{l}\text { Creating a List of } \\
\text { semi-current } \\
\text { records to be } \\
\text { moved. }\end{array}$ & $\begin{array}{l}\text { Creating a List of } \\
\text { semi-current } \\
\text { records to be } \\
\text { moved. }\end{array}$ & $\begin{array}{l}\text { It is necessary to create a semi- } \\
\text { current records list consisting of } \\
\text { a list of files and a list of file } \\
\text { contents. }\end{array}$ & Used \\
\hline 4 & $\begin{array}{l}\text { Creating Report } \\
\text { of Records } \\
\text { Transfer }\end{array}$ & $\begin{array}{l}\text { Creating Report of } \\
\text { Records Transfer }\end{array}$ & $\begin{array}{l}\text { Creating Report } \\
\text { of Records } \\
\text { Transfer }\end{array}$ & $\begin{array}{l}\text { It is necessary to make an } \\
\text { official report on the transfer of } \\
\text { semi-current records as a form } \\
\text { of transfer of authority and } \\
\text { responsibility. }\end{array}$ & Used \\
\hline
\end{tabular}

